\title{
Implementasi Algoritma Zhu-Takaoka pada Aplikasi Pencarian Makanan Khas di Dunia Berbasis Android
}

\author{
Ardiansyah Reza Saragih \\ Program Studi Teknik Informatika, STMIK Budi Darma, Medan, Indonesia
}

\begin{abstract}
Abstrak- Salah satu hal yang tidak boleh dilewatkan oleh seorang traveler adalah mencicipi makanan khas dari negara yang sedang dikunjungi. Tetapi, mereka masih belum tahu makanan khas apa saja yang ada di negara tersebut. Bisa saja menggunakan layanan Google Search untuk mencari informasi dari makanan khas tersebut, akan tetapi membutuhkan koneksi internet. Masalahnya, mungkin saja negara yang sedang dikunjungi sulit untuk mendapatkan koneksi internet, atau traveler tersebut kehabisan dan lupa mengisi kuota internet smartphone miliknya, atau mungkin juga operator seluler smartphone miliknya memang belum bisa dipakai di luar negeri. Jika membeli sim card baru yang sesuai dengan negara yang dikungi tersebut, tentu itu merepotkan. Karena setiap berpindah negara harus membeli sim card baru yang sesuai dengan negara yang dikunjungi. Untuk mengatasi masalah tersebut dibutuhkan sebuah aplikasi sederhana yang dioperasikan pada smartphone berbasis Android yang berguna membantu kita mencari makanan khas dari berbagai negara. Aplikasi ini sangat sederhana dan bersifat offline, yang artinya tidak memerlukan koneksi intenet. Pengguna hanya tinggal memasukan nama negara kemudian akan muncul makanan-makanan khas apa saja yang ada pada negara tersebut. Aplikasi yang dirancangan menggunakan salah satu algoritma pencarian, yaitu Zhu-Takaoka. Algoritma Zhu-Takaoka adalah perkembangan dari algoritma Boyer-Moore.
\end{abstract}

Kata Kunci: Android, Makanan Khas, Zhu-Takaoka

Abstract- One thing that should not be missed by a traveler is tasting the typical food of the country that is being visited. However, they still don't know what special foods are in the country. You can use the Google Search service to find information on these special foods, but you need an internet connection. The problem is, maybe the country that is being visited is difficult to get an internet connection, or the traveler runs out and forgets to fill out his smartphone's internet quota, or maybe his smartphone cellular operator can't be used abroad. If you buy a new sim card that is suitable for the country you visit, of course it is troublesome. Because every time you change countries you have to buy a new sim card that suits the country you are visiting. To overcome this problem, a simple application that is operated on an Android-based smartphone that is useful helps us find special foods from various countries. This application is very simple and is offline, which means it does not require an internet connection. Users only need to enter the name of the country and what foods will appear in that country. Application designed using one of the search algorithms, namely Zhu-Takaoka. The Zhu-Takaoka algorithm is a development of the BoyerMoore algorithm.

Keywords: Android, Typical Food, Zhu-Takaoka

\section{PENDAHULUAN}

Bagi sebagian orang, saat ini smartphone sudah menjadi salah satu kebutuhan pokok. Hampir semua orang sudah pernah menggunakan smartphone mulai dari anak kecil hingga orang dewasa. Seiring pesatnya perkembangan smartphone saat inilah, banyak aplikasi-aplikasi smartphone yang bermunculan untuk melengkapi kecanggihan smartphone tersebut. Aplikasi-aplikasi yang ada pada smartphone bisa dimanfaatkan untuk membantu dan mempercepat pekerjaan kita. Misalkan saja aplikasi kalkulator untuk membantu melakukan perhitungan, aplikasi kamus untuk menerjemahkan bahasa tertentu. Bahkan saat ini sudah ada aplikasi pemesanan tiket yang dapat kita pesan hanya menggunakan smartphone yang kita miliki.

Setiap negara di dunia ini pasti memiliki ciri khas masing-masing yang melambangkan negara tersebut. Sama halnya dengan hal kuliner, setiap negara memiliki makanan. Makanan khas adalah makanan yang biasa dikonsumsi oleh masyarakat yang hanya ada di negara tersebut dan tidak ada di tempat lain. Biasanya makanan khas dibuat dari bahan-bahan yang hanya ada dari negara tersebut serta memiliki cita rasa dan keunikannya masing-masing [1].

Salah satu hal yang tidak boleh dilewatkan oleh seorang traveler adalah mencicipi makanan khas dari negara yang sedang dikunjungi. Tetapi, mereka masih belum tahu informasi tentang makanan khas apa saja yang ada di negara tersebut. Untuk mengatasi masalah tersebut dibutuhkan sebuah aplikasi sederhana yang dioperasikan pada smartphone berbasis Android yang berguna membantu kita mencari makanan khas dari berbagai negara. Aplikasi ini sangat sederhana dan bersifat offline, yang artinya tidak memerlukan koneksi intenet. Pengguna hanya tinggal memasukan nama negara kemudian akan muncul makanan-makanan khas apa saja yang ada pada negara tersebut. Aplikasi ini nantinya akan menggunakan algoritma pencarian.

Algoritma pencarian adalah algoritma untuk melakukan pencarian sebuah string yang lebih pendek atau disebut pattern dari string yang lebih panjang atau disebut text. Ada beberapa algoritma yang dapat digunakan untuk melakukan pencarian, salah satunya adalah algoritma Zhu-Takaoka. Algoritma Zhu-Takaoka ditemukan oleh R.F.Zhu dan T.Takaoka pada tahun 1989. Algoritma ini menggunakan dua text karakter untuk menghitung pergeseran karakter berdasarkan bad-character. Untuk mencari ketidakcocokan atau mencari seluruh text menggunakan preprocessing hashing. Hal ini efektif untuk pencarian string dua dimensi [2]. 
Berdasarkan penelitian yang berjudul, Implementasi Algoritma Zhu-Takaoka Pada Aplikasi Kamus Istilah Musik Berbasis Android yang ditulis oleh, Gutman Togatorop, Aan Erlansari, dan Funny Farady Coastera, dalam penelitian tersebut algortima Zhu-Takaoka berhasil melakukan proses pencarian pada istilah-istilah musik.

\section{METODE PENELITIAN}

\subsection{Makanan Khas}

Makanan khas adalah makanan asli hasil dari olahan dari suatu tempat tertentu yang biasanya dikonsumsi oleh masyarakat di tempat tersebut. Biasanya makanan khas ini dibuat dari bahan-bahan yang ada di tempat tersebut dan memiliki rasa yang unik, melambangkan tempat dimana makanan khas tersebut berasal [1].

\subsection{Algoritma}

Algoritma adalah suatu prosedur yang jelas untuk menyelesaikan suatu persoalan dengan menggunakan langkahlangkah tertentu dan terbatas jumlahnya. Istilah algoritma pertama kali ditemukan oleh seorang ahli dalam bidang matematika yang berkebangsaan Arab bernama Abu Ja'far Muhammad Ibnu Musa Al-Kwarizmi. Yang dikatakan benar dari sebuah algoritma adalah, jika algoritma tersebut berhasil mengeluarkan output yang benar dari semua kemungkinan input. Algoritma sering memiliki langkah pengulangan (iterasi) atau memerlukan keputusan (logika boolean dan perbandingan) sampai tugasnya selesai. Biasanya juga sebuah algoritma memiliki sifat bisa dihitung (computable) atau bisa diukur (measurable) [3].

\subsection{Algoritma Zhu-Takaoka}

Algoritma Zhu-Takaoka merupakan algoritma hasil modifikasi dari algoritma pencocokan string algoritma BoyerMoore yang diciptakan oleh Boyer R.S dan Moore J.S pada tahun 1977. Algoritma Zhu-Takaoka kemudian dikembangkan oleh Zhu Rui Feng dan Tadao Takaoka yang dipublikasikan pada tahun 1986. Algoritma ZhuTakaoka memiliki ciri-ciri yang sama dengan algoritma Boyer-Moore dalam proses pencarian string, yaitu adanya preprocessing, right-to-left scan, bad character rule, dan good suffixes rule. Walaupun memiliki persamaan dalam proses pencarian string, dua algoritma ini tetap memiliki perbedaan, yaitu terletak pada tahap penentuan bad character rule. Dimana pada algoritma Boyer-Moore, bad character hanya terdiri array satu dimensi, sedangkan pada algoritma Zhu-Takaoka dimodifikasi menjadi array dua dimensi.

Pada tahap preprocessing algoritma Zhu-Takaoka membangun tabel bad character 2 dimensi karena algoritma tersebut menghitung untuk pasangan karakter. Kompleksitas waktu dari tahap preprocessing adalah $\mathrm{O}(\mathrm{m}+\mathrm{o} 2)$ dan kompleksitas waktu fase pencarian adalah $\mathrm{O}(\mathrm{mn})$. Proses inti pencarian algoritma Zhu-Takaoka yaitu dilakukan dengan teknik right-to-left scan rule. Teknik ini membandingkan pattern yang dicari dengan sumber text dimulai dari kanan ke kiri [2].

Menjalankan prosedur preZTBc (Preprocessing Zhu-Takaoka Bad Character) dan preBmGs (Preprocessing Boyer-Moore Good Suffixes) untuk mendapatkan inisialisasi.

1. Menjalankan prosedur preZTBc. Fungsi dari prosedur ini adalah untuk menentukan berapa besar pergeseran yang dibutuhkan untuk mencapai karakter tertentu pada pattern dari dua karakter pattern terakhir/terkanan. Hasil dari prosedur preZTBc disimpan pada tabel ztBc.

2. Menjalankan prosedur preBmGs. Sebelum menjalankan isi prosedur ini, prosedur suffix dijalankan terlebih dulu pada pattern. Fungsi dari prosedur suffix adalah memeriksa kecocokan sejumlah karakter yang dimulai dari karakter terakhir/terkanan dengan sejumlah karakter yang dimulai dari setiap karakter yang lebih kiri dari karakter terkanan tadi. Hasil dari prosedur suffix disimpan pada tabel suff. Jadi suff[i] mencatat panjang dari suffix yang cocok dengan segmen dari pattern yang diakhiri karakter ke-i.

3. Dengan prosedur preBmGs, dapat diketahui berapa banyak langkah pada pattern dari sebeuah segmen ke segmen lain yang sama yang letaknya lebih kiri dengan karakter di sebelah kiri segmen yang berbeda. Prosedur preBmGs menggunakan tabel suff untuk mengetahui semua pasangan segmen yang sama. Hasil dari prosedur preBmGs disimpan pada tabel bmGs. Kemudian dilakukan proses pencarian string dengan menggunakan hasil dari prosedur preBmGc dan preBmGs, yaitu tabel $b m B c$ dan $B m G s$.

\section{ANALISA DAN PEMBAHASAN}

Pencarian makanan khas di dunia menggunakan salah satu algoritma pencarian, yaitu Zhu-Takaoka. Dimana algoritma akan melakukan proses pencarian semua karakter pada text berdasarkan pattern yang sudah ditentukan. Pada algoritma Zhu-Takaoka, ketika pattern yang dicari sudah ditemukan, proses pencarian akan terus dilakukan jika panjang karakter pada text masih memungkinan.

Pada proses pencarian makanan khas di dunia ini, menentukan terlebih dahulu pattern atau kata kunci yang akan dicari. Kemudian algortima akan melakukan proses pencocokan pada tiap karakter text untuk menemukan pattern yang dicari. Setelah selesai, akan muncul hasil ditemukan atau tidaknya pattern yang dicari. Jika ditemukan, kemungkinan akan ada beberapa pilihan nama negara yang cocok dengan pattern atau kata kunci yang 
dicari. Kemudian memilih salah satu negara, maka akan muncul daftar beberapa makanan khas yang ada di negara tersebut.

Aplikasi pencarian makanan khas dirancang menggunakan algoritma pencarian yaitu algoritma ZhuTakaoka sebagai solusi dalam melakukan pencarian terhadap pattern yang dijadikan sebagai acuan untuk melakukan pencarian karakter yang sesuai dengan pattern tersebut. Dalam algoritma pencarian secara umum dirumuskan sebagai berikut:

1. Teks (text), yaitu sebuah long string yang panjang $\mathrm{n}$ karakter.

2. Pattern, yaitu sebuah string dengan panjang $m$ karekater $(\mathrm{m}<\mathrm{n})$ yang akan dicari dalam text.

Dalam algoritma pencocokan string, teks diasumsikan berada dalam memori sehingga bila ingin mencari string di dalam sebuah arsip, maka semua isi arsip perlu dibaca terlebih dahulu kemudian disimpan di dalam memori. Jika pattern muncul lebih dari sekali di dalam teks, maka pencarian hanya akan memberikan keluaran berupa lokasi pattern ditemukan pertama kali.

Berikut ini adalah langkah-langkah atau cara kerja dari algortima Zhu-Takaoka dalam contoh kasus melakukan pencarian pattern pada text dengan contoh kasus seperti berikut.

Tabel 1. Data Sampel Makanan Khas

\begin{tabular}{cll}
\hline No. & \multicolumn{1}{c}{ Nama Negara } & \multicolumn{1}{c}{ Makanan Khas } \\
\hline 1. & Indonesia & Karedok, Trancam, Sate Sarepeh \\
2. & Malaysia & Char Kuey Tiaw, Nasi Lemak, Ikan Asam \\
3. & Singapura & Ayam Buah Kluwak, Mi Hokkian, Popiah \\
4. & Vietnam & Pho Xao, Beef Pho, Ca Kho To \\
5. & Thailand & Tom Kha Gai, Yum Nua, Som Tam \\
6. & Filipina & Bulalo, Lumpiang Ubod, Kare-Kare \\
7. & Korea & Bulgogi, Miyeok Guk, Kimbap \\
8. & Jepang & Takoyaki, Tempura Handmaki, Miso Soup \\
9. & India & Kedgeree, Egg Paratha Aloo Gobi \\
10. & Tiongkok & Capcay, Fuyunghai, Pek Cam Kee \\
\hline
\end{tabular}

Langkah 1: Membuat Tabel $z t B c$

Untuk memudahkan proses mencari tabel $z t B c$ langkah awal adalah dengan menemukan tabel $b m B c$, yaitu dengan mengidentifikasi setiap perpindahan.

Tabel 2. $b m B c$ Awal

\begin{tabular}{|l|c|c|c|}
\hline Index & 0 & 1 & 2 \\
\hline Karakter & S & I & A \\
\hline Nilai $\mathrm{OH}$ & $?$ & $?$ & $?$ \\
\hline
\end{tabular}

Keterangan:

1. Index adalah indeks dari pattern.

2. Karakter adalah pattern yang akan dicari.

3. Nilai Occurrence Heuristic $(\mathrm{OH})$ adalah nilai pergeseran Bad Character.

Untuk mengisi nilai $\mathrm{OH}$, melakukan pencacahan di setiap karakter pada pattern. Pencacahan dimulai dari karakter ke-2 paling kanan $($ Index $=$ Length $($ pattern $)$ - 2) dari pattern. Untuk langkah pertama perpindahan diisi dengan angka bernilai 1 .

Tabel 3. Mencari Nilai OH (Pergeseran ke-1)

\begin{tabular}{|l|c|c|c|}
\hline \multicolumn{4}{|c|}{ Index = Length $($ pattern $)-2=3-2=1$} \\
\hline Index & 0 & 1 & 2 \\
\hline Karakter & $\mathrm{S}$ & $\mathrm{I}$ & $\mathrm{A}$ \\
\hline \multicolumn{4}{|c|}{} \\
\hline
\end{tabular}

Bandingkan setiap karakter yang dicacah terhadap karakter yang terdapat pada tabel $b m B c$ sebelumnya. Jika karakter yang dicacah tidak ditemukan dalam tabel tersebut, maka tambahkan karakter tersebut $b m B c$ dan nilai $\mathrm{OH}$ diisi dengan jumlah pindah karakter yang sedang dibandingkan. Untuk perbandingan pertama, bandingkan karakter pertama dengan nilai null.

Tabel 4. Mencari Nilai OH (Perbandingan ke-1)

\begin{tabular}{|l|c|l|c|}
\hline \multicolumn{2}{|c|}{ Bandingkan I dengan null } & \multicolumn{2}{c|}{ Hasil } \\
\hline \multicolumn{2}{|c|}{$b m B c$ (awal) } & \multicolumn{2}{c|}{$b m B c$ (akhir) } \\
\hline Karakter & Null & Karakter & I \\
\hline Nilai OH & Null & Nilai OH & 1 \\
\hline
\end{tabular}


Pada pencacahan karakter selanjutnya, dilakukan pada index sebelumnya dikurangi 1, yaitu pada index 0. Dan jumlah perpindahan diubah menjadi 6 .

Tabel 5. Mencari Nilai OH (Pergeseran ke-2)

\begin{tabular}{|l|c|c|c|}
\hline \multicolumn{4}{|c|}{ Index $=1-1=0$} \\
\hline Index & 0 & 1 & 2 \\
\hline Karakter & $\mathrm{S}$ & $\mathrm{I}$ & $\mathrm{A}$ \\
\hline \multicolumn{4}{|c|}{ Pindah $=2$} \\
\hline
\end{tabular}

Pada perbandingan kedua, bandingkan karakter S yang ada pada index 0 dengan karakter I yang berada pada index sebelumnya. Karena karakter S tidak ditemukan, maka karakter S dimasukan kedalam tabel $b m B c$ dengan nilai $\mathrm{OH}$ sejumlah perpindahan, yaitu 2.

Tabel 6. Mencari Nilai OH (Perbandingan ke-2)

\begin{tabular}{|l|l|l|c|c|}
\hline \multicolumn{2}{|c|}{ Bandingkan S dengan I } & \multicolumn{3}{c|}{ Hasil } \\
\hline \multicolumn{2}{|c|}{$b m B c($ awal $)$} & \multicolumn{3}{c|}{$b m B c$ (akhir) } \\
\hline Karakter & I & Karakter & I & S \\
\hline Nilai OH & 1 & Nilai OH & 1 & 2 \\
\hline
\end{tabular}

Pencacahan selanjutnya merupakan proses pencacahan terakhir, karena index sebelumnya adalah 0 , oleh sebab itu pencacahan dilakukan pada index paling kanan dikurang dengan 1, yaitu pada index 2. Dan jumlah perpindahan diubah menjadi 3 .

Tabel 7. Mencari Nilai OH (Pergeseran ke-3)

\begin{tabular}{|l|c|c|c|}
\hline \multicolumn{4}{|c|}{ Index $=3-1=3$} \\
\hline Index & 0 & 1 & 2 \\
\hline Karakter & $\mathrm{S}$ & $\mathrm{I}$ & $\mathrm{A}$ \\
\hline \multicolumn{4}{|c|}{ Pindah $=3$} \\
\hline
\end{tabular}

Pada perbandingan kedua, bandingkan karakter A yang ada pada index 2 dengan karakter I dan S yang berada pada index sebelumnya. Karena karakter A tidak ditemukan, maka karakter A dimasukan kedalam tabel $b m B c$ dengan nilai $\mathrm{OH}$ sejumlah perpindahan, yaitu 3.

Tabel 8. Mencari Nilai OH (Perbandingan ke-3)

\begin{tabular}{|l|c|c|l|c|c|c|}
\hline \multicolumn{3}{|c|}{ Bandingkan A dengan I, S } & \multicolumn{4}{c|}{ Hasil } \\
\hline Karakter & $\mathrm{I} m B c$ (Awal) & $\mathrm{S}$ & Karakter & $\mathrm{I}$ & $\mathrm{S}$ & $\mathrm{A}$ \\
\hline Nilai OH & 1 & 2 & Nilai OH & 1 & 2 & 3 \\
\hline
\end{tabular}

Untuk mendapatkan hasil akhir dari proses ini pada bagian $b m B c$ (akhir), masukan setiap Nilai OH masing-masing karakter ke dalam karakter pattern.

Tabel 9. $b m B c$ Akhir

\begin{tabular}{|l|c|c|c|}
\hline Index & 0 & 1 & 2 \\
\hline Karakter & S & I & A \\
\hline Nilai OH & 2 & 1 & 3 \\
\hline
\end{tabular}

Tabel $b m B c$ akhir merupakan acuan untuk menentukan tabel $z t B c$. Langkah selanjutnya adalah masukan semua karakter yang terdapat pada sumber teks dan buatlah menjadi dua dimensi, karakter yang dimasukan diurutkan sesuai abjad tak berulang.

Tabel 10. $z t B c$ Awal

\begin{tabular}{|c|c|c|c|c|c|c|c|}
\hline & A & D & E & I & N & O & S \\
\hline A & & & & & & & \\
\hline D & & & & & & & \\
\hline E & & & & & & & \\
\hline I & & & & & & & \\
\hline N & & & & & & & \\
\hline O & & & & & & & \\
\hline S & & & & & & & \\
\hline
\end{tabular}

Setelah tabel dua dimensi terbentuk, langkah selanjutnya adalah mengisi tabel dengan cara melihat karakter pada baris dan karakter pada kolom. Untuk mengisi nilai pada tersebut, ada beberapa aturan sebagai berikut:

1. Jika pola yang dicari ada, maka masukan nilai $\mathrm{OH}$ karakter kolom.

2. Jika pola yang dicari tidak ada, maka masukan panjang pattern. 
3. Jika karakter pada suatu kolom yang dituju adalah karakter pertama pada pattern, maka masukan nilai $\mathrm{OH}$ karakter tersebut, tanpa melihat karakter baris.

Untuk baris 1 kolom 1 didapat karakter A dan A. Lihat baris pattern pada tabel 8. Untuk pola AA, pola ini tidak ada pada pattern. Maka masukan 3 (aturan 2). Hasilnya dapat dilihat pada tabel berikut

Tabel 11. $z t B c$ (Perbandingan ke-1)

\begin{tabular}{|c|c|c|c|c|c|c|c|}
\hline & A & D & E & I & N & O & S \\
\hline A & 3 & & & & & & \\
\hline D & & & & & & & \\
\hline E & & & & & & & \\
\hline I & & & & & & & \\
\hline N & & & & & & & \\
\hline O & & & & & & & \\
\hline S & & & & & & & \\
\hline
\end{tabular}

Selanjutnya mengisi baris 1 kolom 7 didapat karakter A dan S. Lihat pada tabel 8, pola AS tidak terdapat pada pattern. Tetapi karakter pada kolom 7 adalah baris 1 adalah karakter pertama pada pattern, maka masukan 2 (aturan 3). Hasilnya dapat dilihat pada tabel berikut.

Tabel 12. $z t B c$ (Perbandingan ke-2)

\begin{tabular}{|c|c|c|c|c|c|c|c|}
\hline & A & D & E & I & N & O & S \\
\hline A & 3 & & & & & & 2 \\
\hline D & & & & & & & \\
\hline E & & & & & & & \\
\hline I & & & & & & & \\
\hline N & & & & & & & \\
\hline O & & & & & & & \\
\hline S & & & & & & & \\
\hline
\end{tabular}

Selanjutnya misalkan mengisi baris 7 kolom 4 didapat karakter S dan I. Lihat pada tabel 8, pola SI terdapat pada pattern. Masukan nilai 1 (aturan 1). Hasilnya dapat dilihat pada tabel berikut.

Tabel 13. $z t B c$ (Perbandingan ke-3)

\begin{tabular}{|c|c|c|c|c|c|c|c|}
\hline & A & D & E & I & N & O & S \\
\hline A & 3 & & & & & & 2 \\
\hline D & & & & & & & \\
\hline E & & & & & & & \\
\hline I & & & & & & & \\
\hline N & & & & & & & \\
\hline O & & & & & & & \\
\hline S & & & & 1 & & & \\
\hline
\end{tabular}

Langkah tersebut dilakukan sampai tabel $z t B c$ terisi nilai semua dengan mengikuti langkah-langkah sebelumnya. Maka hasil akhirnya dapat dilihat pada tabel berikut.

Tabel 14. $z t B c$ Akhir

\begin{tabular}{|c|c|c|c|c|c|c|c|}
\hline & A & D & E & I & N & O & S \\
\hline A & 3 & 3 & 3 & 3 & 3 & 3 & 2 \\
\hline D & 3 & 3 & 3 & 3 & 3 & 3 & 2 \\
\hline E & 3 & 3 & 3 & 3 & 3 & 3 & 2 \\
\hline I & 3 & 3 & 3 & 3 & 3 & 3 & 2 \\
\hline $\mathrm{N}$ & 3 & 3 & 3 & 3 & 3 & 3 & 2 \\
\hline $\mathrm{O}$ & 3 & 3 & 3 & 3 & 3 & 3 & 2 \\
\hline S & 3 & 3 & 3 & 1 & 3 & 3 & 2 \\
\hline
\end{tabular}

\section{Langkah 2: Membuat Tabel bmGs}

Setelah mendapatkan hasil akhir pada tabel $z t B c$, maka dilanjutkan dengan membuat tabel akhiran/suffix dari pattern.

Tabel 15. bmGs Awal

\begin{tabular}{|l|c|c|c|}
\hline Index & 0 & 1 & 2 \\
\hline Karakter & S & I & A \\
\hline Nilai MH & $?$ & $?$ & $?$ \\
\hline
\end{tabular}


Keterangan:

1. Index adalah indeks dari pattern.

2. Karakter adalah pattern yang akan dicari.

3. Nilai Match Heuristic (MH) adalah nilai pergeseran good suffix, nilai MH nantinya akan digunakan ketika ditemukan kecocokan pada saat mencocokan string karakter pertama atau lebih.

Untuk mengisi nilai MH, langkah pertama adalah membuat tabel suffix dari kanan ke kiri dan dari kiri ke kanan.

1. Tabel suffix dari kanan ke kiri, kolom suffix diperoleh dari pencacahan pattern yang dimulai dari kanan ke kiri, yaitu dari karakter A sampai karakter S.

2. Tabel suffix dari kiri ke kanan, kolom suffix diperoleh dari pencacahan pattern yang dimulai dari kiri ke kanan, yaitu dari S sampai karakter A.

Tabel 16. Suffix (kanan ke kiri dan kiri ke kanan)

\begin{tabular}{|c|c|c|c|c|c|c|c|}
\hline \multicolumn{4}{|c|}{$\begin{array}{l}\text { Pattern: SIA } \\
\text { (kanan ke kiri) }\end{array}$} & \multicolumn{4}{|c|}{$\begin{array}{r}\text { Pattern: SIA } \\
\text { (kiri ke kanan) }\end{array}$} \\
\hline Index & Prefix & Suffix & Len & Index & Prefix & Suffix & Len \\
\hline 2 & $\mathrm{~A}$ & SI & 2 & 0 & $\mathrm{~S}$ & IA & 2 \\
\hline 1 & IA & $\mathrm{S}$ & 1 & 1 & SI & A & 1 \\
\hline 0 & SIA & Null & 0 & 2 & SIA & null & 0 \\
\hline
\end{tabular}

Keterangan:

1. Pembuatan tabel suffix dari kanan ke kiri berfungsi untuk dijadikan suffix comparator pada tabel suffix.

2. Pembuatan suffix dari kiri ke kanan berfungsi sebagai suffix yang nantinya akan dibandingkan dan digunakan untuk mengisi nilai $\mathrm{MH}$.

Dari tabel 16 akan terbentuk tabel.17, tabel ini berfungsi untuk mencari nilai MH. Suffix Comparator yang terdapat pada tabel 17 diambil dari kolom suffix yang ada pada tabel 3 suffix (kanan ke kiri). Sedangkan baris suffix yang terdapat pada tabel 17 diambil dari kolom suffix yang ada pada tabel 3 suffix (kiri ke kanan). Maka akan terlihat seperti Tabel 17.

Tabel 17. Suffix Lengkap Beserta Suffix Comparator

\begin{tabular}{|l|c|c|c|c|}
\hline \multicolumn{5}{|c|}{ Suffix } \\
\hline Index & 0 & 1 & 2 & \multirow{2}{*}{ Move } \\
\hline Prefix & S & I & A & \\
\hline Suffix & IA & A & null & \\
\hline \multirow{2}{*}{$\begin{array}{c}\text { Suffix } \\
\text { Comparator }\end{array}$} & \multicolumn{3}{|c|}{ SI } & 1 \\
\cline { 2 - 4 } & \multicolumn{3}{|c|}{ Sull } & 2 \\
\hline Nilai MH & $?$ & $?$ & $?$ & 3 \\
\hline
\end{tabular}

Langkah selanjutnya, adalah melakukan pemecahan akhiran pada suffix terhadap tabel suffix comparator. Berikan nilai MH pada tabel bmGs dengan moving long yang berkesesuaian. Terdapat beberapa ketentuan yang dapat menjadi acuan dalam mencari nilai $\mathrm{MH}$, yaitu:

1. Cacah suffix pada masing-masing index terhadap seluruh suffix comparator.

2. Jika length kedua suffix tidak sama panjang, maka potong salah satu suffix yang memiliki length terbesar. Besaran pemotongan suffix disesuaikan dengan nilai length terkecil kearah paling kanan karakter. Jika ditemukan kecocokan antar suffix, bandingkan prefix kedua suffix (jika masing-masing suffix memiliki prefix). Jika prefix yang diperbandingkan adalah sama, maka kecocokan tidak dapat diterima.

3. Lakukan poin 2 hingga index suffix mencapai 0.

4. Untuk index suffix terbesar, secara default akan diberikan nilai 1 pada nilai MH, sedangkan yang lainnya diberikan nilai sesuai dengan nilai move yang diraih.

Untuk proses pertama diberikan nilai 1 pada nilai $\mathrm{MH}$, karena index terbesar (ketentuan 4). Prosesnya dapat dilihat pada tabel 18 .

\begin{tabular}{|c|c|c|}
\hline \multicolumn{3}{|c|}{ Proses \#1-01 } \\
\hline \multicolumn{3}{|c|}{ Tabel Suffix } \\
\hline Index & 2 & \\
\hline Prefix & A & \\
\hline
\end{tabular}


DOI: 10.30865/json.v1i1.1365

\begin{tabular}{|c|c|c|c|c|c|c|}
\hline Suffix & null & & & & & \\
\hline \multirow{3}{*}{$\begin{array}{l}\text { Suffix } \\
\text { Comparator }\end{array}$} & SI & 1 & \multicolumn{4}{|c|}{$b m G s$} \\
\hline & $\mathrm{S}$ & 2 & Index & 0 & 1 & 2 \\
\hline & null & 3 & Karakter & $\mathrm{S}$ & I & A \\
\hline Nilai MH & \multicolumn{2}{|c|}{1} & Nilai MH & ? & $?$ & 1 \\
\hline
\end{tabular}

Proses kedua, bandingkan karakter suffix dengan suffix comparator. Jumlah karakter yang dibandingkan disesuaikan dengan jumlah karakter yang paling sedikit (ketentuan 2). Ternyata karakter suffix tidak ada yang sama dengan suffix comparator pada setiap perbandingan. Sehingga jumlah perpindahan dimasukan ke dalam nilai $\mathrm{MH}$ yaitu 3.

Tabel 19. Proses 2 preBmGs

\begin{tabular}{|c|c|c|c|c|c|c|c|c|c|}
\hline \multicolumn{3}{|c|}{$\begin{array}{l}\text { Proses \#2-01 } \\
\text { Tabel Suffix }\end{array}$} & & \multicolumn{3}{|c|}{$\begin{array}{l}\text { Proses \#2-02 } \\
\text { Tabel Suffix }\end{array}$} & \multicolumn{3}{|c|}{$\begin{array}{l}\text { Proses \#2-03 } \\
\text { Tabel Suffix }\end{array}$} \\
\hline Index & 1 & \multirow{3}{*}{ 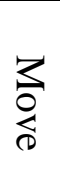 } & & Index & 1 & \multirow{3}{*}{ 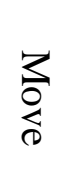 } & Index & 1 & \multirow{3}{*}{ 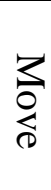 } \\
\hline Prefix & I & & & Prefix & I & & Prefix & I & \\
\hline Suffix & $\mathrm{A}$ & & & Suffix & A & & Suffix & A & \\
\hline \multirow{3}{*}{$\begin{array}{l}\text { Suffix } \\
\text { Comparator }\end{array}$} & SI & 1 & \multirow{3}{*}{\multicolumn{2}{|c|}{$\begin{array}{l}\text { Suffix } \\
\text { Comparator }\end{array}$}} & SI & 1 & \multirow{3}{*}{$\begin{array}{l}\text { Suffix } \\
\text { Comparator }\end{array}$} & SI & 1 \\
\hline & $\mathrm{S}$ & 2 & & & $S$ & 2 & & $S$ & 2 \\
\hline & null & 3 & & & null & 3 & & null & 3 \\
\hline Nilai MH & \multicolumn{2}{|c|}{$?$} & & Nilai MH & \multicolumn{2}{|c|}{$?$} & Nilai MH & \multicolumn{2}{|c|}{$?$} \\
\hline \multicolumn{4}{|c|}{ bmGs } & & & & & & \\
\hline Index & 0 & 1 & 2 & & & & & & \\
\hline Karakter & S & I & A & & & & & & \\
\hline Nilai MH & $?$ & 3 & 1 & & & & & & \\
\hline
\end{tabular}

Proses ketiga, bandingkan karakter suffix dengan suffix comparator. Jumlah karakter yang dibandingkan disesuaikan dengan jumlah karakter yang paling sedikit (ketentuan 2). Ternyata karakter suffix tidak ada yang sama dengan suffix comparator pada setiap perbandingan. Sehingga jumlah perpindahan dimasukan ke dalam nilai $\mathrm{MH}$ yaitu 3.

Tabel 20. Proses 3 preBmGs

\begin{tabular}{|l|r|r|}
\hline \multicolumn{3}{|c|}{ Proses \#3-01 } \\
Tabel Suffix \\
\hline Index & \multicolumn{1}{|c|}{0} & \\
\hline Prefix & S & \multicolumn{2}{c|}{} \\
\cline { 1 - 2 } Suffix & IA & \\
\hline \multirow{2}{*}{$\begin{array}{l}\text { Suffix } \\
\text { Comparator }\end{array}$} & SI & 1 \\
\cline { 2 - 3 } & Sull & 2 \\
\hline Nilai MH & $?$ \\
\hline
\end{tabular}

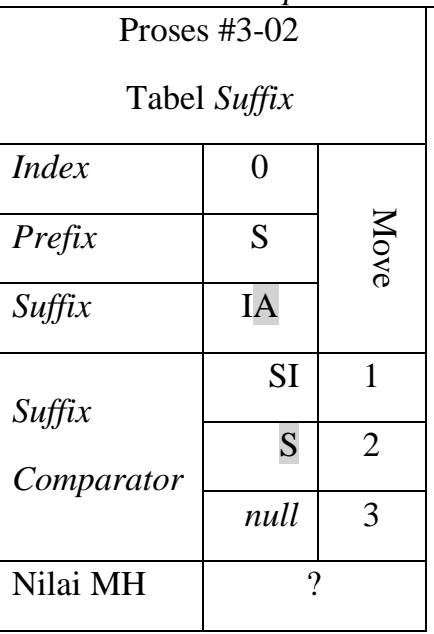

\begin{tabular}{|c|c|c|}
\hline \multicolumn{2}{|c|}{ Tabel Suffix } & \\
\hline Index & 0 & \multirow{3}{*}{$\begin{array}{l}3 \\
2 \\
2\end{array}$} \\
\hline Prefix & $S$ & \\
\hline Suffix & IA & \\
\hline \multirow{3}{*}{$\begin{array}{l}\text { Suffix } \\
\text { Comparator }\end{array}$} & SI & 1 \\
\hline & $\mathrm{S}$ & 2 \\
\hline & null & 3 \\
\hline Nilai MH & ? & \\
\hline
\end{tabular}




\begin{tabular}{|l|c|c|c|}
\multicolumn{4}{|c|}{ bmGs } \\
\hline Index & 0 & 1 & 2 \\
\hline Karakter & S & I & A \\
\hline Nilai MH & 3 & 3 & 1 \\
\hline
\end{tabular}

Hasil akhir dari setiap langkah-langkah sebelumnya dapat dilihat pada tabel 21 berikut.

Tabel 21. $b m G s / z t G s$

\begin{tabular}{|l|c|c|c|}
\hline Index & 0 & 1 & 2 \\
\hline Karakter & $\mathrm{S}$ & $\mathrm{I}$ & $\mathrm{A}$ \\
\hline Nilai MH & 3 & 3 & 1 \\
\hline
\end{tabular}

Karena tabel $b m G s$ dan $z t G s$ sama, maka untuk proses preprocessing sudah selesai dengan hasil yang dapat dilihat pada tabel 14 untuk tabel $z t B c$, dan pada tabel 21 untuk tabel $b m G s$ atau $z t G s$. Selanjutnya sudah bisa melakukan proses pencocokan.

\section{Langkah 3: Melakukan Pergeseran}

Text : INDONESIA

Pattern: SIA

Percobaan ke-1:

\begin{tabular}{|l|c|c|c|c|c|c|c|c|c|}
\hline Index & 0 & 1 & 2 & 3 & 4 & 5 & 6 & 7 & 8 \\
\hline Text & $\mathrm{I}$ & $\mathrm{N}$ & $\mathrm{D}$ & $\mathrm{O}$ & $\mathrm{N}$ & $\mathrm{E}$ & $\mathrm{S}$ & $\mathrm{I}$ & $\mathrm{A}$ \\
\hline Pattern & $\mathrm{S}$ & $\mathrm{I}$ & $\mathrm{A}$ & & & & & & \\
\hline
\end{tabular}

Dari hasil percobaan ke-1, karakter pattern A sejajar dengan karakter text D. Artinya pada percobaan ini terjadi ketidakcocokan. Maka dilakukan pergeseran sejauh 3 karakter (lihat tabel $14 z t B c$ ).

Pergeseran $=3(\mathrm{ztBc}[\mathrm{N}][\mathrm{D}])$

Percobaan ke-2:

\begin{tabular}{|l|c|c|c|c|c|c|c|c|c|}
\hline Index & 0 & 1 & 2 & 3 & 4 & 5 & 6 & 7 & 8 \\
\hline Text & $\mathrm{I}$ & $\mathrm{N}$ & $\mathrm{D}$ & $\mathrm{O}$ & $\mathrm{N}$ & $\mathrm{E}$ & $\mathrm{S}$ & $\mathrm{I}$ & $\mathrm{A}$ \\
\hline Pattern & & & & $\mathrm{S}$ & $\mathrm{I}$ & $\mathrm{A}$ & & & \\
\hline
\end{tabular}

Dari hasil percobaan ke-2, karakter pattern A sejajar dengan karakter text E. Artinya pada percobaan ini terjadi ketidakcocokan. Maka dilakukan pergeseran sejauh 3 karakter (lihat tabel $14 z t B c$ ).

Pergeseran $=3(\mathrm{ztBc}[\mathrm{N}][\mathrm{E}])$

Percobaan ke-3:

\begin{tabular}{|l|c|c|c|c|c|c|c|c|c|}
\hline Index & 0 & 1 & 2 & 3 & 4 & 5 & 6 & 7 & 8 \\
\hline Text & $\mathrm{I}$ & $\mathrm{N}$ & $\mathrm{D}$ & $\mathrm{O}$ & $\mathrm{N}$ & $\mathrm{E}$ & $\mathrm{S}$ & $\mathrm{I}$ & $\mathrm{A}$ \\
\hline Pattern & & & & & & & $\mathrm{S}$ & $\mathrm{I}$ & $\mathrm{A}$ \\
\hline
\end{tabular}

Dari hasil percobaan ke-3, karakter pattern A sejajar dengan karakter text A. Artinya pada percobaan ini terjadi kecocokan. Maka pencocokan dilanjutkan pada karakter sebelum karakter A, yaitu karakter I dan S pada pattern. Terjadi kecocokan pada semua karakter pattern, kemudian algoritma akan menandai lokasi penemuan pattern. Pencocokan tidak dapat dilanjutkan karena karakter text tidak mencukupi. Maka dapat disimpulkan proses percobaan pencocokan selesai.

Kesimpulan:

1. Pada tahap pencocokan dengan algoritma Zhu-Takaoka di atas, pencocokan dilakukan sebanyak 3 iterasi. Ditemukan pada iterasi ke-3.

2. Jumlah index pada text adalah 8, pattern ditemukan pada indeks ke 6-8.

3. Sebagai hasil dari pencarian di atas maka akan muncul nama negara Indonesia dengan beberapa makanan khas yang ada, misalkan Karedok, Trancam, dan Sate Sarepeh. 


\section{KESIMPULAN}

Dari hasil pembahasan disimpulkan, yakni:

1. Proses pencarian makanan khas dilakukan dengan melakukan pencocokan text dengan pattern, dimana text berupa nama suatu negara dan pattern kata kunci yang dicari menggunakan algoritma Zhu-Takaoka.

2. Algoritma Zhu-Takaoka dapat diterapkan dalam perancangan aplikasi pencarian makanan khas di dunia, sehingga diharapkan memudahkan pengguna untuk mencari makanan khas dari suatu negara.

\section{REFERENCES}

[1] V. Nopitasari, I. Oktaviani, and I. Nofikasari, “Aplikasi Resep Masakan Tradisional Berbasis Mobile,” vol. 12, pp. 6180, 2017.

[2] G. Togarotop, A. Erlansari, and F. F. Coastera, "Implementasi Algoritma Zhu-Tajkaoka Pada Aplikasi Kamus Istilah Musik Berbasis Android,” vol. 5, no. 2, pp. 147-153, 2017.

[3] Drs. Suarga. M.Sc. M.Math. Ph.D, Algoritma dan Pemrograman. ANDI Yogyakarta, 2012. 